\title{
Pengaruh Internet Banking, Risiko Kredit dan Ukuran Perusahaan terhadap Kinerja Keuangan Perbankan yang Terdaftar Di Bursa Efek Indonesia Periode 2017 - 2019
}

\author{
Siska Wulandari \\ Universitas Pelita Bangsa \\ siska_tita@pelitabangsa.ac.id \\ Nunuk Novitasari \\ Universitas Pelita Bangsa \\ Nunuknovi23@gmail.com
}

\begin{abstract}
The purpose of this study is to view, analyze, and test the relationship between internet banking and bank performance. The banks used are those listed on the Indonesia Stock Exchange (IDX) in 2019. The method is Multiple Linear Regression by adding two control variables, namely credit risk measured by the NPL ratio and company size measured by the log of total assets with ROA as a measure of the Bank's performance. The findings of this study indicate that internet banking has a positive effect on ROA. The use of internet banking can increase ROA. Commercial banks play a big role in changing (growing) the economy of each country. NPL has a negative and significant effect on ROA. This means that it illustrates an inverse comparison between credit risk and bank performance. If credit risk increases, it will reduce ROA. Company size has a negative and insignificant effect on ROA, it is suspected that the cause is that large assets are not necessarily supported by good management. Company size cannot be used as a guarantee that large companies have good performance, large companies, of course, the costs incurred are also large.resulting in lowering ROA.
\end{abstract}

Keywords: Internet banking, Non Performing Loan, Credit Risk, ROA, Company Size

\section{PENDAHULUAN}

Era globalisasi 4.0 saat ini menuntut setiap orang, perkumpulan organisasi maupun perusahaan dapat memanfaatkan situasi dan kondisi, terlebih perusahaan utamanya sektor perbankan harus mampu membuat peluang untuk mendapatkan keuntungan yang maksimal. Dampak yang luar biasa sebagai akibat dari bertumbuhnya teknologi di masyarakat, yaitu masyarakat dituntut untuk bergerak cepat, bergerak secara tepat guna di dalam kehidupan yang dinamis dan modern dengan menggunakan teknologi yang sudah berkembang. Data APJII (Asosiasi Penyelenggara Jasa Internet Indonesia) melakukan survei kepada penduduk Indonesia diperoleh hasil survei tahun 2018 pengguna internet mencapai 171,17 juta orang dari total populasi penduduk di Indonesia yaitu 264.16 juta orang atau sekitar 64,8\% prosentase penduduk mengakses internet setiap harinya.

Seiring dengan kemajuan teknologi dan adopsi cepat model bisnis inovatif ekonomi di Indonesia dalam sektor keuangan, khususnya produk digital, dengan memungkinkan perusahaan untuk menciptakan nilai dalam lingkungan yang berubah dengan cepat di era teknologi canggih merekomendasikan kebiasaan ke arah yang maju lewat kesederhanaan 
dalam akses jasa perbankan yaitu Financial Technology melalui produk e-banking (mobile banking, internet banking, sms banking) bisa dengan mudah melakukan berbagai transaksi dengan tidak mesti berkunjung ke bank dan dengan kemudahan sekali tekan melalui smartphone atau laptop, dimanapun dan kapanpun selama 24 jam. Transaksi melalui kantor cabang atau ATM (anjungan tunai mandiri) sekarang ini mulai tergeser oleh transaksi via elektronik banking. Kebutuhan perbankan pada masyarakat sudah mulai dialihkan ke perangkat ponselnya dengan menggunakan elektronik banking. Menurut data institute for development economy and finance (INDEF) menunjukkan sebanyak $41 \%$ frekuensi transaksi perbankan nasabah pada 2018 adalah transaksi menggunakan layanan internet perbankan. Angka ini meningkat hampir tujuh kali lipat dibandingkan 2010 dimana hanya 6\% dari frekuensi transaksi perbankan merupakan transaksi menggunakan layanan internet perbankan. Frekuensi transaksi perbankan yang menggunakan ATM pada 2018 sebesar 37\%, turun tipis dibandingkan 2017 sebesar 38\%. Namun jika dibandingkan dengan 2010 dimana 62\% frekuensi transaksi perbankan adalah transaksi dengan menggunakan ATM, angka ini menunjukkan penurunan $40,32 \%$.

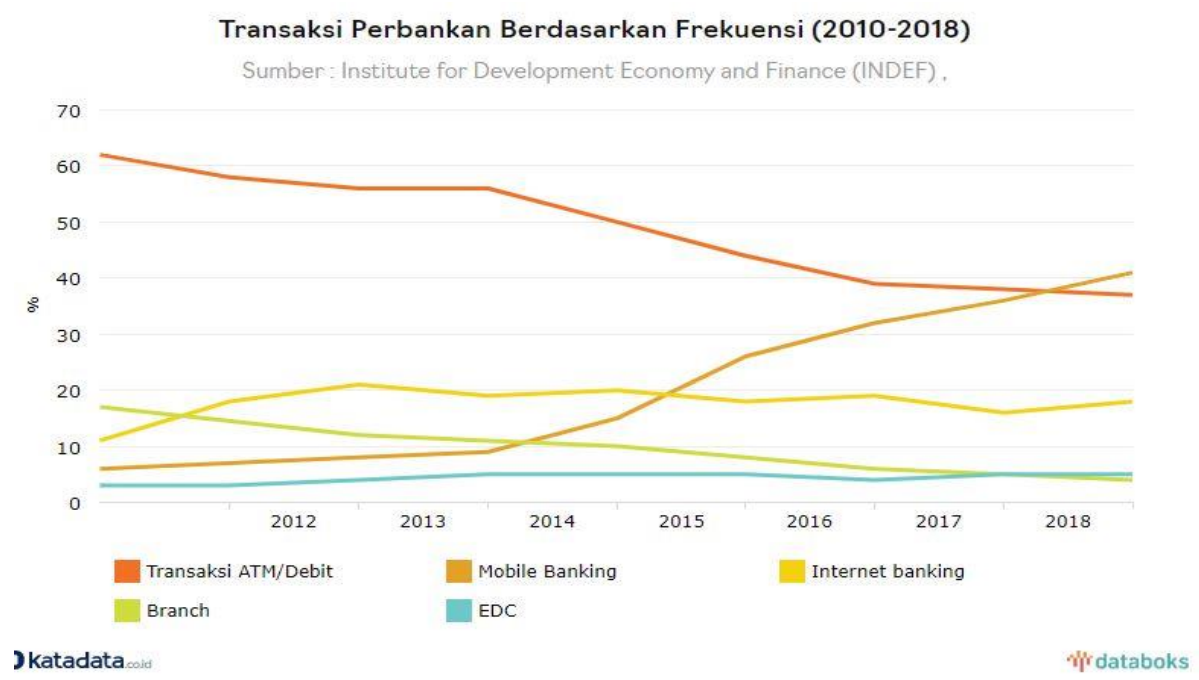

Gambar 1.1 Transaksi Perbankan Berdasarkan Frekuensi (2010-2018)

sumber : INDEFF

Frekuensi transaksi melalui kantor cabang bank pada tahun 2018 hanya sebanyak 4\%. Data itu menunjukkan penurunan tajam dibandingkan periode tahun 2010 di mana 17\% frekuensi transaksi perbankan adalah melalui kantor cabang bank. APJII (Asosiasi Penyedia Jasa Internet Indonesia) merilis hasil survei yaitu data mengenai statistik pengguna internet di Indonesia. Pengguna internet di tahun 2018 adalah sejumlah 171,17 juta penduduk atau $(64,8 \%)$ dari total $100 \%$ jumlah penduduk dan trennya setiap tahun mengalami peningkatan yang signifikan dengan begitu memungkinkan Financial Technology tumbuh dengan cepat di era ini dengan berbagai jenis perkembangan inovasi teknologi yang praktis dalam data APJII (Asosiasi Penyedia Jasa Internet Indonesia) juga menyebutkan dalam 10 tahun terakhir ini pengguna internet mengalami kenaikan.

Layanan internet perusahaan perbankan khususnya di Negara Indonesia mengalami perkembangan begitu pesat alasannya servis yang memberikan kesempatan, kefleksibelan, dan 
kepraktisan dengan mudah ihwal bertransaksi secara online. Lembaga konsultan international McKinsey \& Company menyelenggarakan survey kepada nasabah bank dengan responden lebih dari 900 orang dilakukan di Indonesia tahun 2017. Hasil yang didapat membuktikan nasabah bank di Indonesia sangat tertarik untuk menggunakan inovasi teknologi perbankan digital. Hampir enam dari sepuluh nasabah perbankan Indonesia tertarik untuk menggunakan layanan perbankan digital.

Data pada Bank Negara Indonesia (BNI) per semester I tahun 2019 mencatat transaksi menggunakan layanan via internet mengalami kenaikan sebesar $154,9 \%$ secara tahunan atau dengan kata lain 90 juta transaksi. Sementara itu, jumlah nasabah yang menggunakan layanan internet pada Bank BNI terus - menerus mengalami kenaikan dari tahun - tahun sebelumnya, per akhir juni 2019 dicatat sebesar 3.78 juta, mengalami kenaikan dari tahun sebelumnya yaitu sebesar 2,02 juta atau naik 87,2\% . Menurut laporan keuangan kontan pada Bank Central Asia (BCA) nilai total transaksi menggunakan layanan internet pada Bank BCA mengalami kenaikan menjadi Rp 918 triliun dari periode sebelumnya yaitu $\mathrm{Rp} 606$ triliun atau naik 51,5\% yoy pada semester I akhir tahun 2019, setidaknya penggunaan layanan internet pada Bank BCA pada periode semester I di tahun 2019 total transaksinya tumbuh 31,85\% atau mencapai Rp 890 juta transaksi dengan begitu tentu dapat menambah nilai image kinerja keuangan sektor perbankan agar dapat bersaing dengan perusahaan keuangan lain dan pembiayaan di perbankan menggunakan aplikasi yang mudah dapat dipercepat dengan adanya aplikasi yang sederhana, efektif, efisien dan menjangkau costumer secara luas. Adanya inovasi layanan internet banking proses pembiayaan dapat lebih cepat dan terukur dengan begitu kesempatan yang didapat dari penggunaan inovasi di bidang internet banking tersebut adalah sesuatu yang akan menimbulkan perubahan yang besar untuk memperluas jaringan perbankan untuk melengkapi gaya hidup masyarakat dan supaya literasi masyarakat dibidang keuangan bertambah. Peningkatan pengguna internet banking ini memiliki potensi akan terus meningkat dan hal ini menjadi peluang yang bagus untuk institusi keuangan.

Banyaknya inovasi - inovasi baru dalam sistem pembayaran merupakan akibat dari berkembangnya sistem pembayaran yang berbasis elektronik yang bermaksud untuk memberikan keleluasaan atau fleksibilitas, kesederhanaan dan efisiensi dalam kegiatan bisnis (Sudarsono, 2015). Penelitian oleh Akhisar et al., (2015) menjelaskan bahwa electronic banking signifikan mempengaruhi kinerja perbankan. Penelitian ini bertentangan dengan penelitian yang dilakukan oleh Eze (2016) yang menyatakan bahwa electronic banking tidak memiliki dampak terhadap kinerja perbankan.

\section{LANDASAN TEORI \\ Kinerja Keuangan}

Kinerja suatu perusahaan adalah seberapa efisien dan efektif sebuah organisasi atau seberapa baik organisasi itu menetapkan dan mencapai tujuan yang memadai. Bagi investor, informasi tentang kinerja tersebut dapat digunakan utuk melihat apakah mereka akan mempertahankan investasi mereka. Menurut Fahmi (2016) kinerja keuangan adalah suatu analisis yang dilakukan untuk melihat sejauh mana suatu perusahaan telah melaksanakan dengan menggunakan aturan-aturan pelaksanaan keuangan secara baik dan benar. Kinerja perusahaan merupakan suatu gambaran tentang kondisi keuangan suatu perusahaan yang dianalisis dengan alat-alat analisis keuangan, sehingga dapat diketahui mengenai baik buruknya keadaan keuangan suatu perusahaan yang mencerminkan prestasi kerja dalam periode tertentu. Hal ini sangat penting agar sumber daya digunakan secara optimal dalam menghadapi perubahan lingkungan. Menurut Rudianto (2013) kinerja keuangan adalah hasil 
atau prestasi yang telah dicapai oleh manajemen perusahaan dalam mengelola aset perusahaan secara efektif selama periode tertentu. Kinerja keuangan sangat dibutuhkan oleh perusahaan untuk mengetahui dan mengevaluasi tingkat keberhasilan perusahaan berdasarkan aktivitas keuangan yang telah dilaksanakan. Penilaian kinerja keuangan merupakan salah satu yang dapat dilakukan oleh pihak manajemen agar dapat memenuhi kewajibannya terhadap para penyandang dana dan juga untuk mencapai tujuan yang telah ditetapkan oleh perusahaan. Dua aspek yang sering digunakan dalam menilai kinerja adalah efisiensi dan efektifitas. Efisiensi menggambarkan hubungan input dan output. Sedangkan efektifitas merupakan gambaran hubungan output pada suatu tujuan tertentu.

\section{Internet Bangking}

Alat pembayaran non tunai memberikan manfaat kepada perekonomian, antara lain: tingkat kepuasan konsumen yang semakin bertambah dengan berkurangnya biaya transaksi, adanya sumber pendapatan bagi penyedia jasa pembayaran non tunai, peningkatan kecepatan transaksi, pertumbuhan ekonomi, dan tingkat kesejahteraan (Yazid \& Suryanto, 2016). Internet banking merupakan pemanfaatan teknologi internet sebagai media untuk melakukan transaksi yang berhubungan dengan transaksi perbankan. Kegiatan ini menggunakan jaringan internet sebagai perantara atau penghubung antara nasabah bank dan pihak bank. Selain itu bentuk transaksi yang dilakukan bersifat maya atau tanpa memerlukan proses tatap muka antara nasabah dan petugas bank yang bersangkutan (Direktorat Penelitian dan Pengaturan Perbankan Bank Indonesia). Menurut Zakaria (2012) Internet banking memungkinkan bank untuk meningkatkan kumpulan data nasabah, di mana manajemen dapat membuat rekayasa keuangan yang mampu meningkatkan kemampuan menilai potensi kreditur, mengukur kelayakan kredit pinjaman potensial untuk memprediksi risiko yang terkait dengan peminjam melalui mekanisme standar seperti pemeringkat kredit.

\section{Risiko Kredit}

Menurut Kasmir (2014) kredit atau pembiayaan adalah adanya suatu kegiatan atas dasar kesepakatan dan persetujuan antara si pemberi dan penerima atau bank dengan pihak lain atas hal bank melakukan penyediaan uang atau tagihan yang mengharuskan dan wajib kepada pihak yang dibiayai mengembalikan tagihan dan uang tersebut pada waktu yang telah ditentukan atau disepakati (jatuh tempo) dengan memberikan imbalan atau bagi hasil. Menurut Kasmir (2012) untuk mengukur risiko terhadap kredit yang disalurkan dengan membandingkan kredit macet dengan kredit yang disalurkan maka digunakan rasio risiko kredit untuk menilai hal tersebut. Rasio yang dapat digunakan untuk mengukur risiko kredit dalam penelitian ini adalah Non Performing Loan (NPL), penghitungannya yaitu bandingkan antara kredit bermasalah terhadap total kredit. BR Pasaribu (2018) berpendapat tentang Non Performing Loan (NPL) menggambarkan ukuran besarnya risiko kredit yang dialami bank. Semakin mendekati nilai 0 nilai dari Non Performing Loan (NPL) maka semakin tidak ada atau nihil risiko kredit yang ditanggung oleh pihak bank. Sedangkan menurut Kasmir (2013) Non Performing Loan (NPL) adalah 2 unsur yaitu pertama dari pihak perbankan dalam menganalisis, maupun dari pihak nasabah yang secara sengaja atau tidak dalam kewajibannya tidak melakukan pembayaran yang menjadi penyebab hambatan dalam kredit. Kredit bermasalah menyebabkan penurunan kinerja bank dan penyebab bank tidak efisien sebagai akibat dari ketidaklancaran pembayaran pokok pinjaman dan bunga hal itu sejalan dengan Darmawi (2011) Non Performing Loan (NPL) merupakan sebagai salah satu pengukuran dari rasio risiko usaha bank yang menunjukkan besarnya risiko kredit bermasalah yang ada pada suatu bank. Atas teori para ahli tersebut dapat 
ditarik kesimpulan Non Performing Loan (NPL) dalam dunia perbankan pastinya ada yang namanya resiko kredit tidak ada satu bank didunia ini yang tidak mempunyai resiko kredit nah dalam pengukurannya sendiri, besar atau kecil nilainya kredit bermasalah digunakan rasio ini dan rasio ini dapat menjelaskan berapa besar masalah yang akan dihadapi dan diterima oleh suatu perusahaan akibat dari tidak lancarnya debitur dalam membayar hutangnya kepada bank.

\section{Ukuran Perusahaan}

Ukuran Perusahaan (Firm Size) adalah skala untuk menentukan besar kecilnya suatu perusahaan yang dapat diproksikan dengan beberapa cara, antara lain total aktiva (Total Assets) dan total penjualan (Saemargani \& Mustikawati, 2015). Definisi tersebut menjelaskan bahwa ukuran perusahaan merupakan skala pengukuran yang menunjukkan besar atau kecilnya suatu perusahaan melalui total aktiva dan total penjualan yang dimiliki. Menurut Aprianingsih (2016) menjelaskan bahwa ukuran suatu perusahaan tercermin dari total aset yang dimiliki, semakin besar aset perusahaan maka semakin besar ukuran perusahaan, begitupun sebaliknya. Definisi tersebut menjelaskan bahwa ukuran perusahaan dapat dinilai melalui total aset yang dimiliki. Aset memiliki arti yang sama dengan aktiva yaitu kekayaan yang dimiliki oleh perusahaan untuk menjalankan usahanya. Menurut Sari (2014) menjelaskan bahwa yang biasa digunakan untuk menilai ukuran perusahaan adalah jumlah tenaga kerja, total penjualan, total utang dan total aset. Melalui definisi tersebut terdapat unsur penilaian yang berbeda dibandingkan kedua definisi sebelumnya yaitu junlah tenaga kerja dan total utang. Jumlah tenaga kerja menunjukkan banyaknya tenaga kerja yang dimiliki oleh perusahaan baik tenaga kerja langsung atau tenaga kerja tidak langsung.

\section{Pengembangan Hipotesis}

\section{Hubungan Internet Bangking dengan Kinerja Keuangan}

Hasil penelitian Yuliati et al (2020) menyatakan bahwa dalam hal profitabilitas bank dengan internet banking memiliki ROA dan ROE yang lebih baik dari tanpa memiliki internet bankin. Hernando (2007) mengatakan bahwa internet banking digunakan sebagai pelengkap bukan pengganti cabang fisik, namun peningkatan profitabilitasnya dilihat dari penuruan biaya overhead. Setengah tahun pertama ROA meningkat signifikan dan dalam tiga tahun ROA meningkat secara terusmenerus secara signifikan. Penelitian yang dilakukan oleh Sofiana (2014) dengan membuat pemetaan terhadap bank-bank penyedia layanan internet banking. Pemetaan kinerja perbankan menunjukkan $60 \%$ bank-bank penyedia internet banking belum memiliki kinerja yang baik, namun di pemetaan pengaruh internet banking $45,71 \%$ dari total penyedia layanan internet banking terhadap pengaruh yang besar dari layanan internet banking tersebut. Berdasarkan penelitian sebelumnya, maka diajukan hipotesis sebagai berikut :

H1 : Internet Bangking berpengaruh positif dan signifikant terhadap kinerja keuangan perbankan

\section{Hubungan Risiko Kredit dengan Kinerja Perusahaan}

Dalam menyalurkan kredit kepada masyarakat, bank akan menghadapi risiko kredit. Siamat (2005) mengemukakan bahwa risiko kredit didefinisikan sebagai risiko yang dikaitkan dengan kemungkinan kegagalan klien membayar kewajibannya atau risiko dimana debitur tidak dapat melunasi pinjamannya. Untuk menentukan kualitas kredit maka diperlukan adanya ukuran tertentu. Kolektibilitas kredit merupakan penggolongan kredit berdasarkan kategori tertentu guna memantau kelancaran pembayaran kembali oleh debitur (Paramitha et al., 2014). Pada penelitian ini, risiko kredit diproksikan dengan rasio Non Performing Loan (NPL). Rasio 
ini menggambarkan kemampuan manajemen bank dalam mengelola kredit bermasalah. Semakin kecil NPL, semakin kecil risiko kredit yang ditanggung pihak bank. Dalam pemberian kredit, bank perlu melakukan analisis terhadap kemampuan debitur untuk membayar kembali pinjamannya. Setelah pemberian kredit, bank wajib melakukan pemantauan terhadap penggunaan kredit dan kemampuan serta kepatuhan debitur dalam memenuhi kewajibannya. NPL yang tinggi akan meningkatkan biaya pencadangan aktiva produktif dan biaya-biaya lainnya, sehingga akan berdampak pada penurunan kinerja keuangan bank. Berdasarkan penelitian sebelumnya, maka diajukan hipotesis sebagai berikut :

H2 : Risiko Kredit berpengaruh positif dan signifikant terhadap kinerja keuangan perbankan

\section{Hubungan Ukuran Perusahaan dengan Kinerja Perusahaan}

Ukuran perusahaan bisa dilihat dari total aset perusahaan. Perusahaan dengan total aset yang besar mencerminkan kemapanan perusahaan. Perusahaan yang sudah mapan biasanya kondisi keuangannya juga sudah stabil. Informasi tersebut sekaligus menjadi bahan untuk keperluan pengungkapan informasi kepada pihak eksternal seperti investor dan kreditor, sehingga tidak memerlukan tambahan biaya yang besar untuk melakukan pengungkapan lebih luas. Dengan demikian, perusahaan yang besar mempunyai biaya produksi informasi yang lebih rendah daripada perusahaan kecil. Suatu perusahaan besar dan mapan akan mudah untuk menuju ke pasar modal. Kemudahan untuk berhubungan dengan pasar modal maka berarti fleksibilitas lebih besar dan tingkat kepercayaan investor juga lebih besar karena mempunyai kinerja operasional yang lebih besar. Perusahaan besar mampu menarik minat investor yang lebih besar dibandingkan dengan perusahaan kecil, karena mempunyai fleksibilitas penempatan investasi yang lebih baik (Putra \& Chabachib, 2013). Penelitian yang dilakukan oleh Theacini (2014), mengungkapkan bahwa ukuran perusahaan memiliki pengaruh positif terhadap kinerja keuangan perusahaan. Berdasarkan penelitian sebelumnya, maka diajukan hipotesis sebagai berikut :

H3 : Ukuran Perusahaan berpengaruh positif dan signifikant terhadap kinerja keuangan perbankan

\section{METODE PENELITIAN}

Penelitian ini dilakukan pada perusahaan sektor perbankan yang terdaftar di Bursa Efek Indonesia periode tahun 2017 - 2019. Jenis data yang digunakan dalam penelitian ini adalah data kuantitatif yang diperoleh dari data laporan keuangan perusahaan sektor perbankan yang terdaftar di BEI tahun 2017 - 2019. Populasi dalam penelitian ini adalah keseluruhan perusahaan sektor perbankan yang terdaftar di Bursa Efek Indonesia (BEI) periode penentuannya per tahun 2019 berjumlah 45 perusahaan. Jumlah sampel dalam penelitian ini adalah hanya beberapa perusahaan perbankan yang termasuk kategori menggunakan layanan internet banking dan belum menggunakan layanan internet banking yang memenuhi kriteria sebagai berikut :

a. Perusahaan perbankan sudah terdaftar di Bursa Efek Indonesia (BEI) sebelum 2017 sampai dengan tahun 2019.

b. Selama periode pengamatan perbankan pilihan tersebut listing di Bursa Efek Indonesia (BEI)

c. Data keuangan yang dimiliki perusahaan lengkap untuk diambil dan diolah datanya sebagai variabel terikat, dan variabel bebasnya dalam penelitian ini serta laporan keuangan tahunan yang memadai 
Dari semua perusahaan sektor perbankan yang terdaftar di Bursa Efek Indonesia (BEI) ada 24 perusahaan yang terpilih dengan periode waktu yang digunakan adalah 3 tahun jadi jumlah data yang diolah untuk dijadikan sampel adalah 72 data kemudian karena data oulier, dikeluarkan dari sampel. Metode Analisis yang digunakan adalah regresi linier berganda dengan software eviews sebagai alat analisis.

\section{HASIL DAN PEMBAHASAN}

\section{UJI T}

Digunakan pada penelitian ini untuk menguji hipotesis dalam penelitian ini secara parsial guna menunjukkan apakah ada pengaruh tiap variabel bebas secara individu terhadap variabel terikat. Uji t digunakan untuk pengujian koefisien regresi masing-masing variabel bebas terhadap variabel terikat untuk mengetahui seberapa besar pengaruh antara masing - masing variabel. Pengujian ini dilakukan dengan menggunakan nilai signifikan 0,05 . Penerimaan atau penolakan hipotesis dilakukan dengan nilai sig dan nilai koefisien beta. Jika nilai signifikan > 0,05 maka variabel bebas dalam penelitian ini tidak berpengaruh signifikan terhadap variabel terikat sehingga hipotesis ditolak. Jika nilai signifikan < 0,05 maka variabel bebas (independen) dalam penelitian ini berpengaruh signifikan terhadap variabel terikat (dependen), dan nilai koefisien beta harus searah dengan hipotesis yang diajukan maka hipotesis diterima. Berikut disajikan tabel 1 sebagai hasil dari uji t sebagai berikut :

\section{Tabel 1. Hasil Uji t}

Dependent Variable: ROA

Method: Least Squares

Date: 06/27/20 Time: 17:57

Sample: 146

Included observations: 46

\begin{tabular}{lrlll}
\hline \hline \multicolumn{1}{c}{ Variable } & Coefficient & Std. Error & t-Statistic & Prob. \\
\hline \multicolumn{1}{c}{ C } & 1.956663 & 0.784129 & 2.495334 & 0.0166 \\
NPL & -2.612435 & 0.424088 & -6.160128 & 0.0000 \\
BANK_SIZE & -0.007539 & 0.092430 & -0.081567 & 0.9354 \\
D_IBANKING & 0.955801 & 0.424250 & 2.252916 & 0.0295 \\
\hline \hline R-squared & 0.605067 & Mean dependent var & 1.638043 \\
Adjusted R-squared & 0.576857 & S.D. dependent var & 1.018440 \\
S.E. of regression & 0.662489 & Akaike info criterion & 2.097317 \\
Sum squared resid & 18.43348 & Schwarz criterion & 2.256329 \\
Log likelihood & -44.23829 & Hannan-Quinn criter. & 2.156884 \\
F-statistic & 21.44904 & Durbin-Watson stat & 1.684694 \\
Prob(F-statistic) & 0.000000 & & & \\
\hline \hline
\end{tabular}

Sumber : output eviews 10, diolah penulis 2020 
Berikut penjelasan tabel 1 hasil uji $\mathrm{t}$ :

a. Pengaruh Internet Banking terhadap Kinerja Keuangan Perusahaan

Hasil pengujian analisis regresi linear berganda menunjukan hasil thitung untuk variabel internet banking adalah sebesar 2.252916 sementara nilai t tabel dengan $\alpha=5 \%$ dan $\mathrm{df}=(\mathrm{n}-\mathrm{k})$, $\mathrm{df}=$ 43 dimana nilai $t_{\text {tabel }}=(2.252916>1.68107)$, untuk nilai probabilitas yaitu sebesar 0,0295 yang lebih kecil dari 0,05 maka H1 diterima H0 ditolak. Hal ini berarti bahwa Internet Banking memiliki dampak yang signifikan terhadap return on asset dan pengaruhnya adalah positif. Hasil ini sesuai dengan penelitian yang dilakukan oleh Sakanko (2019) menyatakan bahwa adopsi sistem pembayaran elektronik memiliki pengaruh yang signifikan terhadap kinerja keuangan bank.

b. Pengaruh Risiko Kredit Sebagai Variabel Kontrol Terhadap Kinerja Perusahaan Perbankan Hasil pengujian hipotesis kedua menunjukan hasil thitung untuk variabel Risiko Kredit adalah sebesar -6.160128 sementara nilai $\mathrm{t}_{\text {tabel }}$ dengan $\alpha=5 \%$ dan $\mathrm{df}=(\mathrm{n}-\mathrm{k})$, $\mathrm{df}=43$ dimana nilai $\mathrm{t}_{\text {tabel }}=(-6.160128<1.68107)$, kemudian jika dilihat dari nilai probabilitasnya yaitu sebesar 0,0000 yang lebih kecil dari 0,05 maka $\mathrm{H} 2$ diterima. Hal ini berarti bahwa Risiko Kredit memiliki pengaruh signifikan terhadap kinerja keuangan perusahaan dan pengaruhnya adalah negatif. Hasil ini sesuai dengan penelitian yang dilakukan oleh Sudaryanti (2018) menyatakan bahwa NPL berpengaruh terhadap ROA dan pengaruhnya adalah negatif.

\section{c. Pengaruh Ukuran Perusahaan Sebagai Variabel Kontrol Terhadap Kinerja Perusahaan Perbankan}

Hasil pengujian hipotesis kedua menunjukan hasil thitung untuk variabel ukuran perusahaan adalah sebesar -0.081567 sementara nilai $t_{\text {tabel }}$ dengan $\alpha=5 \%$ dan $\mathrm{df}=(\mathrm{n}-\mathrm{k}), \mathrm{df}=43$ dimana nilai $t_{\text {tabel }}=(-0.081567<1.68107)$, kemudian jika dilihat dari nilai probabilitasnya yaitu 0.9354 $>$ 0,05 maka H3 ditolak dan H0 diterima. hasil ini menunjukan bahwa ukuran perusahaan berpengaruh negatif tidak signifikan terhadap kinerja perusahaan perbankan. Dengan demikian $\mathrm{H}_{3}$ ditolak. Hasil ini sesuai dengan penelitian yang dilakukan oleh Putra (2013) menyatakan bahwa ukuran perusahaan berpengaruh tidak signifikan terhadap ROA dan pengaruhnya adalah negatif.

\section{Koefisien Determinasi}

$\mathrm{R}^{2}$ atau Koefisien determinasi pada dasarnya untuk melihat, mengukur dan menilai sebagaimana tentang variabel independen atau variabel bebas memberikan sumbangan berupa pengaruh terhadap variabel terikat atau variabel dependennya dengan begitu informasi mengenai model regresi terestimasi atau dengan kata lain nilai dari koefisien determinasi ini dapat dilihat dari hasil nilai $\mathrm{R}^{2}$ (koefisien determinasi). Nilai $\mathrm{R}^{2}$ (koefisien determinasi) adalah di antara 0 dan 1. Apabila nilai koefisien semakin mendekati angka 1 maka semakin baik dan kuat garis regresinya karena dinilai mampu dalam menerangkan data actual, tetapi apabila nilai koefisiennya semakin mendekati angka 0 maka pengaruh variabel independen terhadap variabel dependen semakin lemah. Pada penelitian ini dapat dilihat pada tabel 1 diketahui nilai adjusted $\mathrm{R}$ square sebesar 0.605067 , hal tersebut berarti bahwa 60,5\% variabel Kinerja Perusahaan Perbankan maka dapat dijelaskan oleh internet banking, risiko kredit, dan ukuran perusahaan dan sisanya 39,5\% dijelaskan oleh variabel lain diluar persamaan. 


\section{Analisis Regresi Linear Berganda}

Analisis ini dipakai atau digunakan untuk mengetahui seberapa besar pengaruh antar variabel terikat dengan variabel bebas yang digunakan, arah hubungan antara masing - masing variabel bebas terhadap variabel terikat hubungannya variabel tersebut positif atau negatif sekaligus untuk memprediksi nilai dari variabel - variabelnya, nilai variabel independen mengalami kenaikan atau penurunan. Adapun variabel dalam penelitian ini dapat dinyatakan dalam model sebagai berikut:

$$
Y=1.956663+0.955801 D-2.612435 X_{1}-0.007539 X_{2}+\ldots+e
$$

Hasil perhitungan linear berganda yaitu nilai koefisien regresi variabel internet banking sebesar 0.955801 dengan arah positif, hal ini berarti memperlihatkan artinya setiap nilai atau meningkatnya penggunaan internet banking sebesar satu satuan maka kinerja keuangan Perbankan yang diukur dari return on assets akan bertambah atau meningkat sebesar 0.955801 . Perhitungan linear berganda nilai koefisien regresi variabel Risiko Kredit sebesar -2.612435 dengan arah negatif, hal ini memperlihatkan setiap ada kenaikan nilai Risiko Kredit sebesar satu satuan maka kinerja keuangan Perbankan akan menurun sebesar -2.612435. Perhitungan linear berganda didapat nilai koefisien regresi variabel Ukuran Perusahaan sebesar -0.007539 dengan arah negatif, hal ini menunjukkan bahwa setiap terjadi kenaikan nilai dari Ukuran Perusahaan sebesar satu satuan, maka akan berdampak pada penurunan kinerja keuangan perusahaan perbankan sebesar -0.007539 .

\section{Pengaruh internet banking terhadap kinerja perusahaan perbankan yang terdaftar di Bursa Efek Indonesia}

Hasil uji hipotesis pertama membuktikan bahwa internet banking memiliki pengaruh positif dan signifikan terhadap kinerja perusahaan. penerimaan hipotesis pertama ini mengindikasi bahwa adanya inovasi layanan di bidang finansial, utamanya internet banking dengan kemajuan teknologi yang pesat di perusahaan akan menambah pendapatan atau profit sehingga kinerja perusahaan perbankan yang diindikatori dari return on asset akan mengalami peningkatan. Hal ini dikaitkan juga dengan hasil R Square 0.605067 (60,5\%) untuk internet banking, total aset, dan resiko kredit menunjukan bahwa variabel independen dalam penelitian ini mampu memberikan informasi hingga 60,5\% masing - masing sehingga sisanya 39,5\% tidak dapat dijelaskan dalam penelitian ini tetapi dapat dijelaskan dari variabel lain diluar penelitian ini. Hal ini sejalan dengan penelitan yang dilakukan oleh Sakanko (2019) menunjukkan bahwa perbankan elektronik berpengaruh signifikan terhadap profitabilitas bank, dan penelitian yang dilakukan oleh Torki (2020) yang juga menyatakan bahwa elektronik banking secara signifikan berpengaruh terhadap kinerja keuangan perbankan dan arah pengaruhnya adalah positif. Namun, penelitian ini tidak sejalan dengan Eze (2016) hasil penelitian ini menyatakan bahwa internet banking tidak berpengaruh signifikan terhadap profitabilitas bank.

\section{Pengaruh risiko kredit sebagai variabel kontrol terhadap kinerja perusahaan perbankan yang terdaftar di Bursa Efek Indonesia}

Hasil uji hipotesis kedua membuktikan bahwa risiko kredit memiliki dampak yang signifikan terhadap kinerja perusahaan dan pengaruhnya adalah negatif. Penerimaan hipotesis kedua ini mengindikasi bahwa aktifitas perbankan untuk memperoleh profit adalah dari aktifitas kredit sehingga apabila terjadi kredit macet akan berpengaruh terhadap penurunan 
return on asset perbankan. Selain itu, risiko kredit merupakan salah satu kerugian bank. Hal ini sejalan dengan penelitian yang dilakukan oleh Sudaryanti (2018) hasil penelitian ini menyatakan risiko kredit berpengaruh dan signifikan terhadap kinerja perbankan dan pengaruhnya adalah negatif menunjukkan bahwa apabila terjadi peningkatan nilai pada risiko kredit maka dapat mempengaruhi penurunan nilai pada laba.

\section{Pengaruh ukuran perusahaan sebagai variabel kontrol terhadap kinerja perusahaan perbankan yang terdaftar di Bursa Efek Indonesia}

Hasil uji hipotesis ketiga menunjukkan bahwa ukuran perusahaan berpengaruh tetapi tidak signifikan terhadap kinerja perusahaan dan pengaruhnya adalah negatif. Ketidaksignifikannya ini dapat berarti memperlihatkan bahwa total aset (ukuran perusahaan) bukan kategori faktor penyebab yang mempengaruhi ROA. Total asset perusahaan yang besar belum menjamin akan menghasilkan return on asset yang maksimal hal ini dapat disebabkan oleh belum didukungnya pengelolaan yang bagus, arah nilainya juga negatif menandakan juga semakin ukuran perusahaan itu besar kebutuhan akan biaya - biaya juga besar (contohnya : biaya pemeliharaan mesin, alat, gedung, biaya sumber daya manusia, beban administrasi, beban umum, dll) bisa jadi menjadi penyebab penurunan nilai ROA. Hasil penelitian ini berbeda dengan penelitian yang dilakukan oleh Sudaryanti (2018) hasil penelitian ini menyatakan ukuran perusahaan berpengaruh dan signifikan terhadap kinerja perusahaan tetapi, hasil penelitian ini sejalan dengan penelitian yang dilakukan oleh Putra (2013) menemukan bahwa Ukuran Perusahaan (Size) berpengaruh negatif dan tidak signifikan terhadap ROA perusahaan faktor penyebabnya adalah ukuran perusahaan bukan faktor utama yang mempengaruhi ROA dengan begitu ukuran perusahaan yang besar akan membutuhkan biaya operational yang besar dan tentunya akan menurunkan tingkat ROA.

\section{KESIMPULAN}

Internet bangking berpengaruh positif dan signifikan terhadap kinerja perusahaan, artinya penggunaan layanan internet banking pada bank dapat meningkatkan ROA. Bank komersial memainkan peran besar dalam pertumbuhan dan perkembangan ekonomi setiap negara. Untuk memaksimalkan kinerja mereka, mereka mendorong inovasi yang bertujuan untuk meningkatkan efisiensi dan efektivitas dalam pemberian layanan. Revolusi dalam inovasi dan teknologi dan penggunaannya dalam kegiatan perbankan telah membawa kepercayaan pada transformasi operasi sistem perbankan manual menjadi perbankan berbasis teknologi. Risiko kredit berpengaruh negatif dan signifikant terhadap kinerja perusahaan, artinya menggambarkan perbandingan terbalik antara risiko kredit dengan kinerja perusahaan. Meningkatnya risiko kredit dapat berpengaruh terhadap penurunan ROA. Risiko kredit merupakan sumber kerugian bagi perbankan oleh karena itu, risiko kredit harus diminimalisir oleh perbankan. Ukuran Perusahaan berpengaruh negatif dan tidak signifikan, artinya apabila total aset mengalami peningkatan akan menurunkan ROA, penyebabnya adalah ukuran perusahaan yang besar tersebut belum tentu didukung manajemen yang bagus. Ukuran perusahaan tidak bisa dijadikan sebagai jaminan bahwa perusahaan yang besar memiliki prestasi kinerja yang bagus. Ukuran perusahaan yang besar, maka biaya yang dikeluarkan oleh perusahaan tersebut besar juga, dengan begitu akan menurunkan nilai ROA. 


\section{DAFTAR PUSTAKA}

Akhisar, I., Tunay, K. B., \& Tunay, N. (2015). The effects of innovations on bank performance: The case of electronic banking services. Procedia-Social and Behavioral Sciences, 195, 369-375.

Aprianingsih, A., \& Yushita, A. N. (2016). Pengaruh Penerapan Good Corporate Governance, Struktur Kepemilikan, Dan Ukuran Perusahaan Terhadap Kinerja Keuangan Perbankan. Jurnal Profita: Kajian Ilmu Akuntansi, 4(4).

$\mathrm{Br}$ pasaribu (2018). pengaruh non performing loan dan capital adequacy ratio terhadap profitabilitas perusahaan perbankan yang terdaftar di bursa efek indonesia tahun 20122016.

Darmawi, H. (2011). Manajemen perbankan. Jakarta: Bumi Aksara.

Eze, G. P., \& Egoro, S. (2016). Electronic banking and profitability of commercial banks in Nigeria. Journal of Finance and Economic Research, 3(1), 202-222.

Fahmi, I. (2016). Pengantar Manajemen Keuangan, Cetakan Kelima. Bandung: CV Alfabeta.

Hernando, I., \& Nieto, M. J. (2007). Is the Internet delivery channel changing banks' performance? The case of Spanish banks. Journal of Banking \& Finance, 31(4), 10831099.

Kasmir. (2014). Analisis Laporan Keuangan (satu. Ceta). PT Raja Grafindo Persada.

Paramitha, N. N. K. D., Suwendra, I. W., \& Yudiaatmaja, F. (2014). Pengaruh Risiko Kredit Dan Likuiditas Terhadap Profitabilitas Pada Perusahaan Perbankan Yang Go Public Periode 2010-2012. Jurnal Manajemen Indonesia, 2(1).

Putra, S. A., \& Chabachib, M. (2013). Analisis pengaruh Ukuran perusahaan, kepemilikan institusional, dan Kepemilikan manajerial terhadap kinerja perusahaan Serta dampaknya terhadap nilai perusahaan (Studi terhadap Perusahaan Manufaktur yang Terdaftar di BEI Tahun 2007-2011). Fakultas Ekonomika dan Bisnis.

Rudianto, E. (2013). Akuntansi Manajemen Informasi Untuk Pengambilan Keputusan Strategis. Jakarta: Erlangga.

Saemargani, F. I., \& Mustikawati, R. I. (2015). Pengaruh ukuran perusahaan, umur perusahaan, profitabilitas, solvabilitas, ukuran kap, dan opini auditor terhadap audit delay. Nominal: Barometer Riset Akuntansi Dan Manajemen, 4(2), 1-15.

Sakanko, M. A., \& David, J. (2019). The Effect of Electronic Payment Systems on Financial Performance of Microfinance Banks in Niger State. Esensi: Jurnal Bisnis Dan Manajemen, 9(2), 143-154. 
Sari, L. R. N. (2014). Pengaruh Ukuran Perusahaan, Leverage dan Good Corporate Governance terhadap Kualitas Laporan Keuangan pada Perusahaan Manufaktur yang terdaftar di BEI tahun 2009-2012. Skripsi. Universitas Negeri Yogyakarta.

Siamat, D. (2005). Manajemen Lembaga Keuangan, Edisi Keempat, Badan Penerbit Fakultas Ekonomi Universitas Indonesia. Jakarta.

Sofiana, T. U. (2014). Analisis pengaruh internet banking terhadap kinerja bank di indonesia dengan metode data envelopment analysis dea dan principal component analysis pca= The analysis of internet banking impact on bank performance in indonesia using data envelopment analysi.

Sudarmadji, A. M., \& Sularto, L. (2007). Pengaruh ukuran perusahaan, profitabilitas, leverage, dan tipe kepemilikan perusahaan terhadap luas voluntary disclosure laporan keuangan tahunan. Proceeding Pesat, 2(53-61).

Sudarsono, M. (2015). Perlindungan konsumen pemegang uang elektronik (e-money) dihubungkan dengan undang-undang nomor 8 tahun 1999 tentang perlindungan konsumen. Jurnal Wawasan Yuridika, 29(2), 896-907.

Sudaryanti, D. S., Sahroni, N., \& Kurniawati, A. (2018). Analisa Pengaruh Mobile Banking Terhadap Kinerja Perusahaan Sektor Perbankan yang Tercatat di Bursa Efek Indonesia. Jurnal Ekonomi Manajemen, 4(2), 96-107.

Theacini, D. A. M., \& Wisadha, I. G. S. (2014). Pengaruh good corporate governance, kualitas laba dan ukuran perusahaan pada kinerja perusahaan. E-Jurnal Akuntansi Universitas Udayana, 7(3), 733-746.

Torki, L., Rezaei, A., \& Razmi, S. F. (2020). The Effects of Electronic Payment Systems on the Performance of the Financial Sector in Selected Islamic Countries. International Journal of Economics and Politics, 1(1), 113-121.

Yazid, H., \& Suryanto, T. (2016). An investigation of factors influencing audit quality according to Islamic audit: a study for the Jakarta Islamic index.

Yuliati, L. N., Dradjat, H. A., \& Simanjuntak, M. (2020). Online bike: Role of perceived technology, perceived risk, and institution-based trust on service usage via online trust. Cogent Business \& Management, 7(1), 1798067.

Zakaria, A. (2012). Analisis pengaruh penerapan internet banking terhadap kinerja perbankan di Indonesia= Analysis of the impact of application of internet banking to banks' performance in Indonesia. 